\title{
Influence of Sikh lifestyle on Guler miniature paintings
}

\author{
Gurdeep Kaur \& Rohita Sharma
}

Department of Business and fine arts, Lovely Professional University, Phagwara, Punjab, India. Email.gurdeepkaurı21@yahoo.in.

Received December 06, 2016; Accepted December 19, 2016; Published January 26, 2017

\begin{abstract}
The scholars of Indian miniature painting observe the Sikh influences on Pahari miniature painting during Sikh dominancy but in actual, Sikhism and its associations with Hill aristocracy were very deep and prior then Maharaja Ranjit Singh and it should not be disremember that Lahore was one of the glorious art capital of Mughals in Punjab from the days of Emperor Akbar. So Sikhs were also not unaware of artistry and painting. Sikh paintings of $19^{\text {th }}$ century reflect splendid lifestyle and fashion adopted by the Sikhs of Lahore during Sikh dominancy in Punjab Plains which reflected in the court paintings of Guler. But the study also focuses to grasp the Sikh lifestyle before, during and after Maharaja Ranjit Singh and its impact on the Rajput rulers of Guler as the results of Sikh-Rajput associations, which buried in Rajput culture of Guler; and later reflected precisely in paintings of Guler during $18^{\text {th }}-19^{\text {th }}$ century. The two different lifestyles under different cultures and ethos merged and influenced each other which reflected in surviving paintings. The study is based on data analysis and explorative method. The study concludes that Sikh lifestyle influenced imprecisely Rajput lifestyle in the beginning but with the expansion of Sikh power, it continuously increased till the last of nineteenth century A.D and emerged and reflected in later court paintings of Guler specifically.
\end{abstract}

Key words: Rajput, Guler, Lahore, dress, Sikh influence, lifestyle.

\section{Sikh-Guler associations:}

The study considers the influences of Sikh lifestyle on Guler miniature paintings from their origin, through Rajput-Sikh connections of either companionships or clashes, along with cultural interactions. Although, Sikh influence reached all over the hill states of the Punjab after Sikh rule in the first quarter of nineteenth century. But Sikh approach to the northern Hills is as old as Sikhism. Connection of Sikhism with the northern Hill States started from the travels of Guru Nanak and extended with the extension of Sikhism. Many scholars usually perceive these influences during the Sikh Empire of Maharaja Ranjit Singh, but ignored the connections of last five Sikh Gurus who lived, travelled and associated with the Hilly areas time to time. During the second half of eighteenth century, through the rakhi system; the Sikh misldars remained connected with Punjab Hills to obtain protection money from the taxes in response to rise the Sikh power in Punjab Plains and Hills and influenced the Rajput aristocracy.

In Punjab Hills, there were various centers of miniature paintings cultivated with Hindu Rajput culture and traditions patronized by Rajput hill rulers in which Guler, a small state

(c) AesthetixMS 2016. This Open Access article is published under a Creative Commons Attribution Non-Commercial 4.0 International License (http://creativecommons.org/licenses/by-nc/4.o/), which permits non-commercial re-use, distribution, and reproduction in any medium, provided the original work is properly cited. For citation use the DOI. For commercial re-use, please contact editor@chitrolekha.com. 
founded by the ruler of Kangra; Hari Chand Katoch; in 1405 A.D, was also a chief centre of miniature painting and remained a popular centre of art till nineteenth century A.D. (Randhawa M. S. and D. S. 1982). Before the Sikh annexation in 1809 A.D., Guler remained part of Mughal Empire till mid eighteenth century and later became subject of Katoch rulers of Kangra. Rajput rulers of Guler; Rup Chand, Man Sigh, Bikram Singh, Raj Singh and Dalip Singh remained connected with the Mughals as Guler was a subject of Mughal Empire during Akbar, Jahangir, Shahjahan and Aurangzeb. During Govardhan Chand (1741-1773), it was a great centre of arts while Prakash Chand (1773-1790) remained under the influence of Kangra rulers Ghamand Chand and his grandson Maharaja Sansar Chand. During Sikh annexation Bhup Singh (1790-1826) and Shamsher Singh (1826-1877) were the rulers of Guler, while in the first Sikh War, Shamsher Singh turned the Sikhs out of Haripur Fort (Hutchison and Vogel 1933, Vol. I, 206-207)

Although Muslim lifestyle was distinct from the Hindus but they inspired each-another during the Muhammaden invasions and continued till Mughals. During Guru Nanak's period; 'Shaikh Hamadani's five conditions for survival of Hindus out of twenty; were forbidden to dress like Muslims, ride on horses with a saddle and bridle, possess any arms like sword or arrows, wear rings and seals on their fingers, sell or drink intoxicating liquor openly' (see Gupta 1984, 26) and during Babur's period, 'A Hindu buttoned his coat to the right, a Muslim to the left. ..... The favourite colour of Hindus was red and yellow, and of the Muslims blue and green. Muslims would not wear red.' (Gupta 1984, 37)

So with the Mughal influence on Rajput lifestyle and painting, the period between last quarter of sixteenth century and first quarter of seventeenth century, which is responsible for the origin of Pahari painting in Punjab Hills, it also belongs to the origin of a new philosophy and its final conversion from Hinduism into Sikhism through baptism by tenth Sikh Guru. With the baptismal ceremony, Sikhs got new identity and style of living which was distinct from both; Mughals and Rajputs. Now with Mughal and Rajput culture, there was a new society made up of Sikhism. There was no particular dress code before the baptismal ceremony done by Guru Gobind Singh. '...the outlandish garb that Nanak wore on his journeys, it was always a combination of styles worn by Hindu Sadhus and Muslim fakirs." A light yellow coloured heavy frock style long robe of 52 lines worn by six Guru; Guru Hargobind in the Gwalior fort is also available today. The references of blue dresses (Latif 1989, 281) are available worn by tenth Guru. But hair, small comb, short breeches, small sword and a steel bangle became compulsory for Sikhs after baptismal ceremony.

Mughal influences were continued after Guru Gobind Singh. Banda Singh Bahadur also worn Mughal court dresses. During Misl period, simple dresses with some alterations in Mughal dresses as simple frock style robes with short breeches and waistbands and 'Dumaala' turbans were in fashion among Sikhs. Mughal influences on Sikh appearances can be seen in the rare Sikh paintings of that period, in which contemporary portraits of Sikh Gurus in Mughal dresses were painted in Punjab Plains and Hills. In actual, tenth Sikh Guru granted the Sikhs a distinct identity from Rajputs and Mughals who were emerged from low caste Hindu society.

\section{Sikh influence on Guler paintings before Maharaja Ranjit Singh}

Rajputs inspired a lot from the Mughals as the result of Mughal-Rajput political relations and interactions which reflected in the various fields of life. Those cultural elements set in the Rajput roots, and practiced regularly. But pursuing those cultural elements and their influences, one can 
faces various complexities to identify their roots and sources of origin and the paths, in which those influences breathed and expressed after various adaptations.

Although Raja Dalip Chand (1695-1741) was associated with tenth Sikh Guru but during the peaceful period of Prakash Chand (1773-1790), the approach and influences of Sikh misaldars begun towards Hills and painters also began to record their meetings. It was the first time, when painters started to draw Sikh characters with their real identities. Court scenes in which males always remained distinct while due to seclusion, Rajput females did not appear in the court scenes but female attendants can be noticed in the surroundings of administrative area. So the Sikh influences can only be observe in the lifestyle of Rajput male members and female attendants. The various objects used by the Sikhs of Punjab Plains began to include in the paintings of Guler by miniaturists and those things became part of Rajput paintings and cannot identified easily and buried in the elements of Guler painting from the period of evolvement and the Sikh elements increased unceasingly with the empowerment of Sikhism. Some common objects were used by the Sikhs during Sikh Gurus and were constant in fashion during eighteenth-nineteenth centuries that reflect the impression of Sikh Gurus on their followers. To see the Sikh influences, it is necessary to identify Sikh idioms which were the part of Sikh identity and lifestyle, reflected in Sikh paintings made for Sikh patrons and expressed in Guler court paintings.

\subsection{Sword-Belts}

In the portraits of Guler rulers earlier from Govardhan Chand, there was no fashion of wearing sword belts over the shoulder, as sword or dagger was always tucked at the waist with the help of waist band or waist belt under Mughal fashion (figure 1). It may be seen held also in the hand of a standing character. It is well known to us that after the order of tenth Sikh Guru, weapons were worn openly by common Sikhs which was against the Mughal orders. The fashion of wearing sword belt or gatra ${ }^{4}$ over the shoulder is a common practice even today among Sikh community (figure 2). Thus, it may only after Sikh influence that, sword belts were worn over the shoulder by Guler rulers and nobles since Prakash Chand of Guler (figure 3) (also see Archer 1973, Vol. II, plate $52)$.

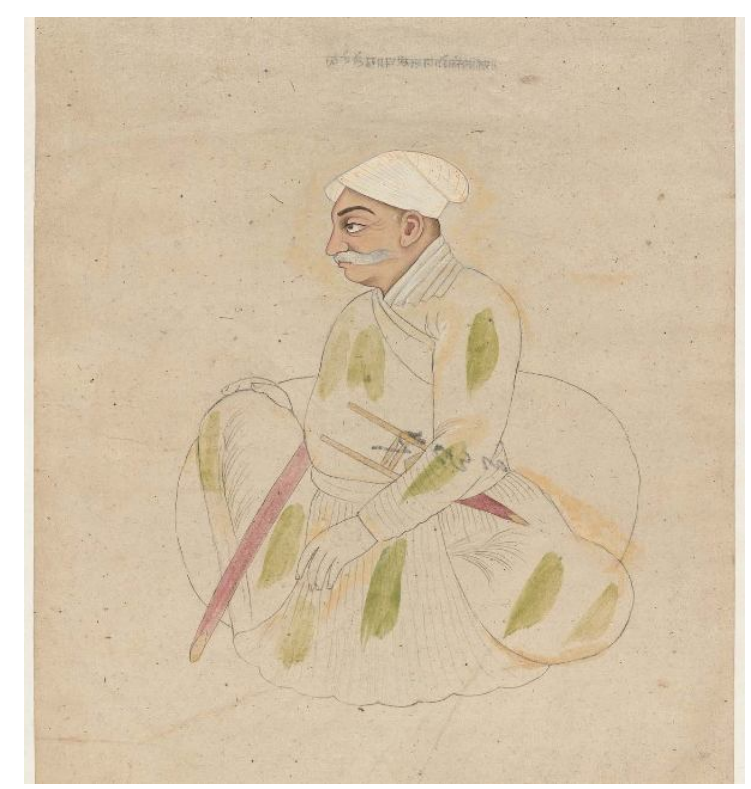

Figure 1. Mian Gopal Singh of Guler seated, Accession no. 17.2722, Museum of fine arts, Boston 
8 Chitrolekha International Magazine on Art and Design, Vol. 6, No. 3, 2016

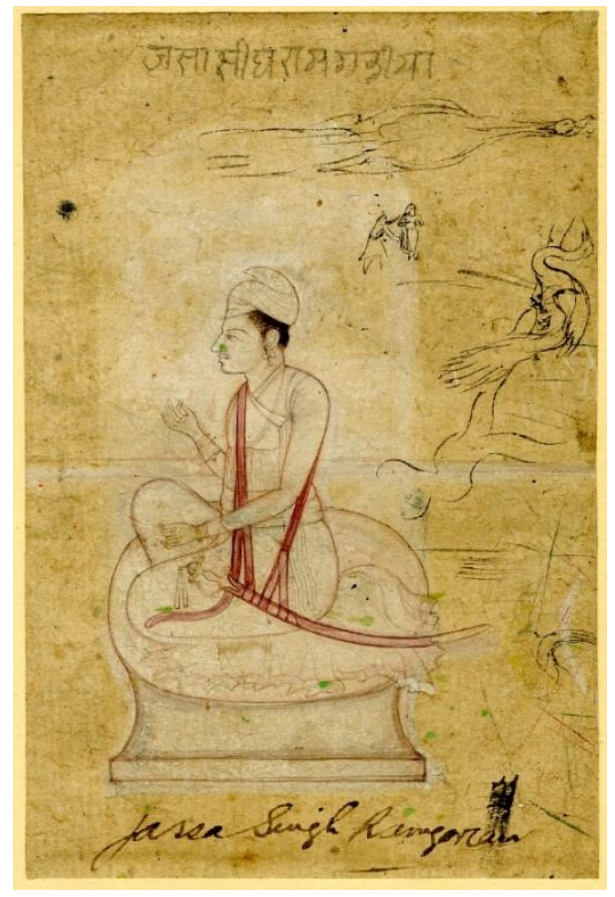

Figure 2. Jassa Singh Ramgarhia, Museum no. 1948, 1009, o.131, British Museum.

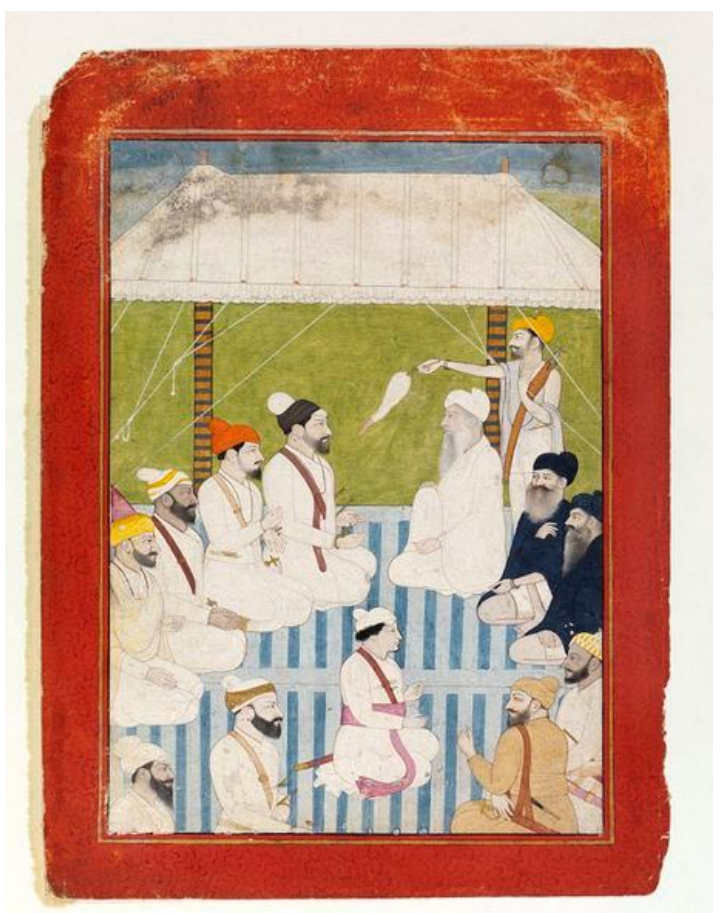

Figure 3. Jai Singh Kanheya (1764-1794) receiving Raja Raj Singh of Chamba, Raja Prakash Chand (1773-179o) of Guler and other Hill princes. Guler, circa 1774 A.D. Museum no. IS.128-1955, Victoria and Albert Museum, London. 


\subsection{Turbans}

The use of turbans by Guler rulers were inspired by Mughal style and followed till Govardhan Chand (1741-1773). But variations of styles of wearing turbans changed through ruler to ruler. Sikh associations also influenced in the form of Sikh turbans. Different types of wearing turbans were popular among Sikhs, in which small conical turbans and wrap over it continued (figure 4) during Maharaja Ranjit Singh. The differences between Rajput and Sikh turbans were precise during Raja Govardhan Chand but later conical turbans became popular during Raja Prakash Chand and it may be seen seldom wearing by Rajput nobles.

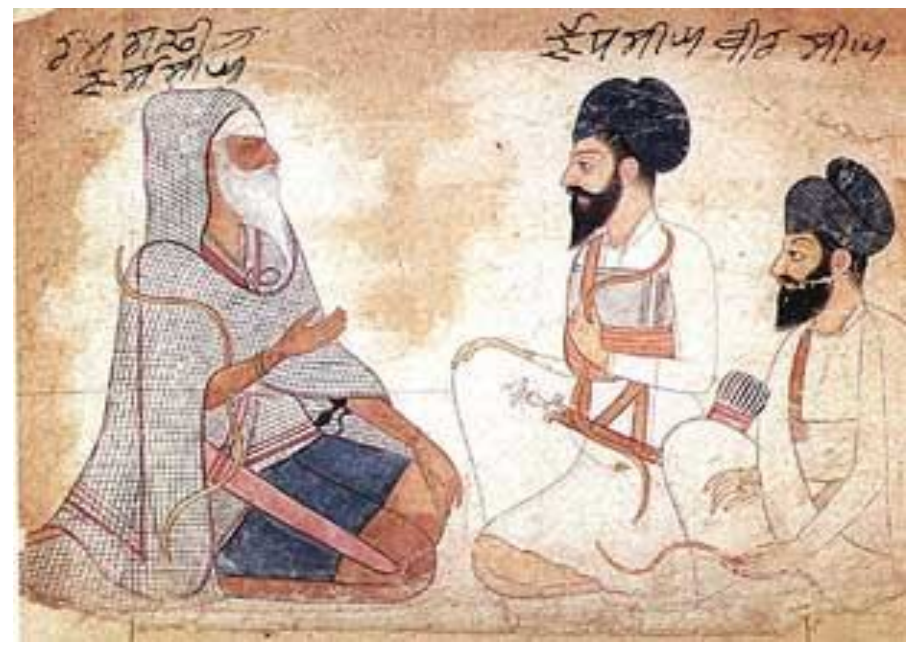

Figure 4. Sardar Jassa Singh Ramgarhia with Jodh Singh and Bir Singh, circa 1780 A.D. Acc. No. 6o.543, National Museum, New Delhi

Goswamy's presumptions that Pandit Seu migrated to Guler from Punjab Plains or Delhi can be useful here to see the influence of the fashion, popularly adopted by the common Sikhs of Punjab Plains. Probably the approach of Jassa Singh Ramgarhia and Jai Singh Kanheya influenced Rajput rulers before Maharaja Ranjit Singh. The Pahari painters were also working for these two Sikh misaldars, it is clear from a sketch of Devi, in which probably the names of patron states of the Guler painters were inscribed including the names of two Sikh patrons. ${ }^{5}$

\subsection{Beard}

The fashion of wearing beard and moustaches is distinct among Hindus and Muslims from centuries. During Babur's period, 'Hindus kept a tuft of hair on their heads, while Muslims trimmed their beards and moustaches in a certain fashion. ${ }^{6}$ During Emperor Jahangir, to identify Sikhs, 'a proclamation was issued requiring the Hindus in general to shave off their beards. Many submitted to this disgrace, but some men of name and position committed suicide to save the honour of their beards. ${ }^{7}$ The rulers of Guler can be seen without beard or in trimmed beard before Govardhan Chand (see Archer 1973, Vol. II, plates 1,2,3,4,5, 6,7,15,20,21,24,38, 48, 49) while Prakash Chand adopted fashion of long beard (see Archer 1973, Vol. II, plates 50,51,52,54) which continued with the Guler rulers till last of the nineteenth century. During Prakash Chand (17731790), the fashion of wearing long beard suddenly appears, so it can be easily presume that probably it came into fashion at Guler during Prakash Chand which is reflected in contemporary paintings but it was compulsion for every Rajput ruler. 


\section{$2.4 \quad$ Sikh Robes}

Mughal robes were ideal for the courts of India. The royals and common people often forced to follow the fashions of imperial personages. Guler rulers often shown wearing collar style frock and plated Mughal robes (figure 5).

Before Maharaja Ranjit Singh; different types of robes were worn by Sikhs in which the design of upper part was different from Mughals as well as Rajputs (figure 2).

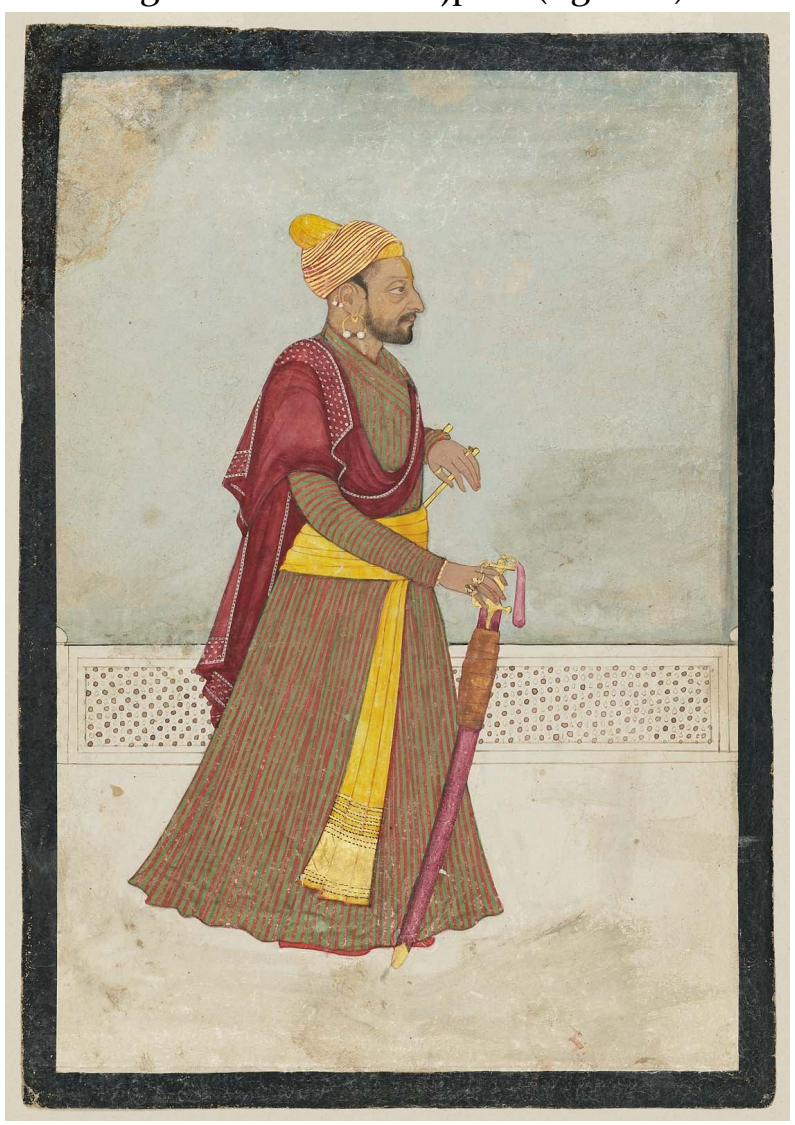

Figure 5. Sri Raja Govardhan Chand of Guler, Accession no. 17.2707, circa 177o A.D. Museum of Fine arts, Boston

\section{$3 \quad$ Precise Sikh influences on Guler paintings during and after Maharaja Ranjit}

\section{Singh:}

After Sikh annexation of Guler in 1809 AD., Hill States were not directly administered by the Sikh Maharaja but paid annual tribute. After Bhup Singh, Shamsher Singh and Jai Singh became the ruler of Guler. Raja Bhup Singh had two sons, Shamsher Singh and Jai Singh. Desa Singh Majithia succeeded Bhup Singh as local governor of the hill States. Rajput and Sikh, both cultures mingled and marital relations also took place between them. Although, the major part of Sikh miniature paintings is portraiture of Sikh Maharaja and Sikh nobles painted in Punjab Plains. These portraits present differences in lifestyles due to personal interests but some fashions were 
common and adopted by all nobles as mark of dignity. Those common and popular elements were observed by the painters working for Sikh patrons and the result was reflected in Sikh paintings.

\subsection{Fitted vest with tight trousers}

During Maharaja Ranjit Singh, fitted vest with tight trousers were much popular and probably Maharaja was also fond of wearing fitted vest with the combination of tight trousers as can be seen in different portraits of Maharaja (figure 6). This fashion was also continued during Maharaja Sher Singh (figure 7).

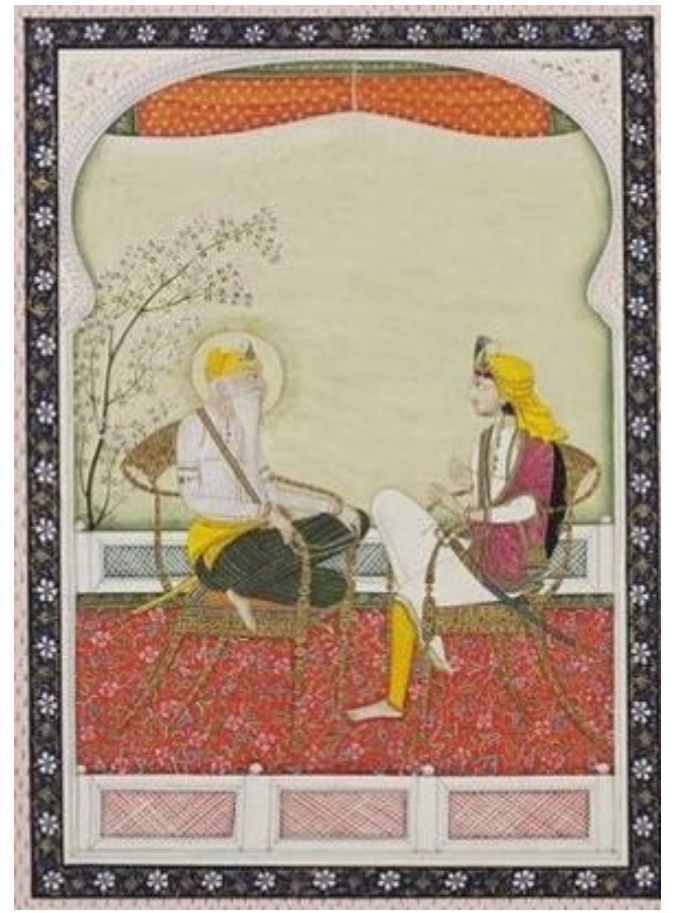

Figure 6. Maharaja Ranjit Singh (1780-1839) seated with Hira Singh (c. 1816-1844) circa 1838-1840, Museum no. IS.114-1953, Victoria and Albert Museum

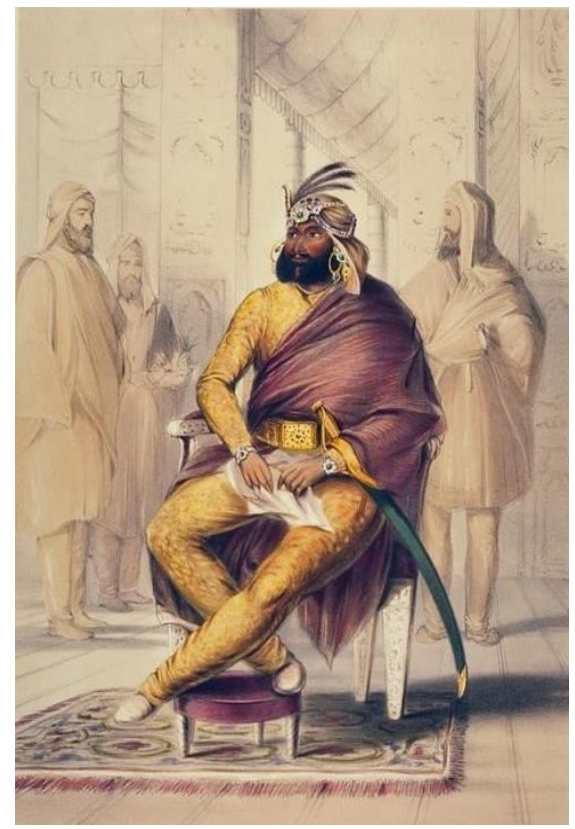


Figure 7. Maharaja Sher Singh 'Portraits of the Princes and People of India' by Emily Eden, Date: 1844, Object ID: 1998.63.2, Asian Art Museum of San Francisco

\subsection{Sikh Robes}

During Maharaja Ranjit Singh; Kashmiri and Multan silk fabrics, silk, fur, Pashmina wool, very soft fabric called muslin, brocade, satin and velvet were popular fabrics. A different type of robe came into fashion in Punjab Plains in which collar neck of Mughal-Rajput style robes was replaced by round neck decorated with different types of designer silk laces attached on it with a line at the chest (figures 8, 9). This alteration can be seen earlier Maharaja Ranjit Singh (figure 2). The frock style of the lower part of the Mughal-Rajput robes was replaced by a divide in front of the robe and legs can be seen between two parts of robe (figure 8, 9) while full sleeves were continued in fashion. It appears that heavy and precious Mughal-Rajput robes replaced by simple light weighted robes. It may be more comfortable while walking and riding for the Sikhs.

Maharaja Ranjit Singh also granted 'Khillats' to the hill Rajput rulers and European visitors on various ceremonial occasions. It may also a reason behind the popularity of Sikh dresses which passed through hill states. Rulers of Guler were also honored by Maharaja Ranjit Singh during their visits to Lahore court (figure 10).

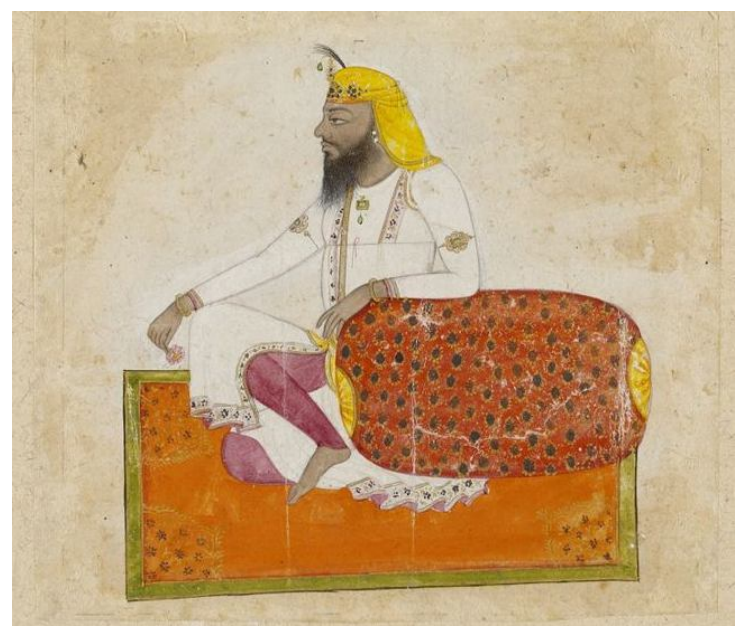

Figure 8. Sikh Sardar. Punjab Plains, c. 1835-1845, Museum no. IS.9-1957, Victoria and Albert Museum

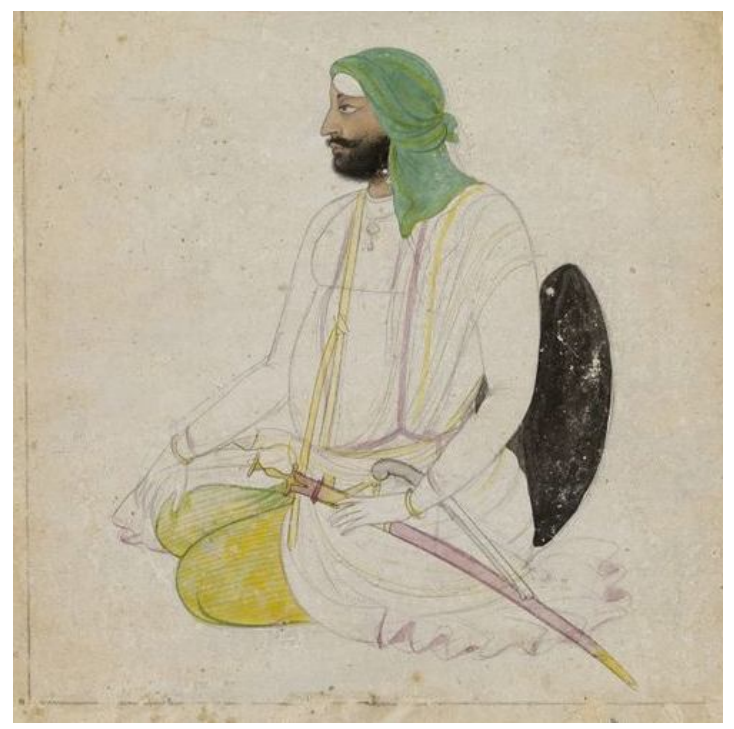


Figure 9. Sikh Sardar. Museum no. IS.15-1957, Victoria and Albert Museum

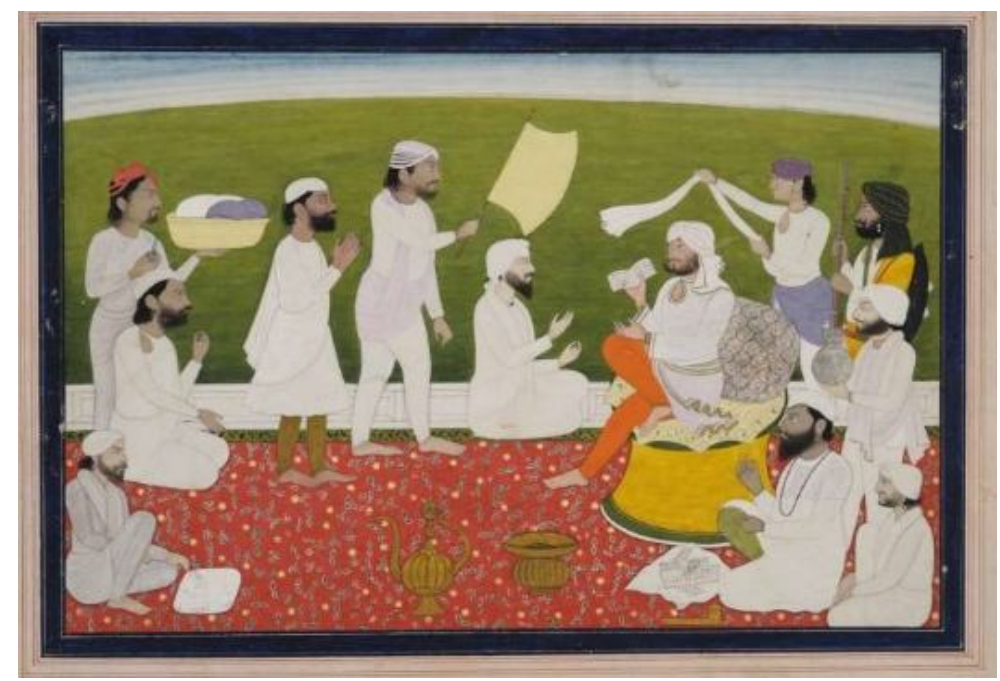

Figure 1o. Raja Shamsher Singh consulting Brahmans in his court. Circa 186o, Guler, Acc. No. 205, Government Museum and Art Gallery, Chandigarh

\subsection{Different styles of Sikh turbans}

In the Sikh paintings, a large variety of Sikh turbans are shown wearing by the Sikhs of Punjab Plains, which became merged with different Rajput turbans (see Archer 1973, Vol. II, plates 62,64,73,74, 76, 78, 8o, 81). During Maharaja Ranjit Singh; Hindus, Muslims, Afghans, Rajputs and Purabias were active in the battalions of Sikhs. The uniforms may be the same but the style of wearing turbans changed person to person with personal comforts and choices. Royal turbans always remained decorated with pearl strings, gems and plume but common populace also decorated their turbans occasionally.

\section{$3.4 \quad$ Beards}

Long beard was in fashion from Prakash Chand and continued till the end of 19th century under the Sikh influence. Long beards and mustaches and partly trimmed beards with Sikh turbans, both were in fashion so Guler Rajputs appeared like Sikh nobles. 'When the Sikhs under Ranjit Singh became the masters of Punjab including the hills, the Rajput rulers to please their new masters gave up shaving and shearing of beards, and long flowing beards became fashionable. ${ }^{8}$

\subsection{Big Umbrella}

Big and long poled royal umbrellas of silk fabric like the modern umbrella of today were also in fashion, which were used by Maharaja and his courtiers during their visits for hunting or expeditions which was an emblem of royalty and also for the protection from heat and water in the summers and rains (figure 11). There are various references that Mughals also used umbrellas 
9 Chitrolekha International Magazine on Art and Design, Vol. 6, No. 3, 2016

but painters did not create the element of umbrella in Mughal paintings. Along with khillats and royal gifts, given by Maharaja Ranjit Singh; royal umbrellas were also the part of gifts for the comfort of royal guests. After the Sikh influence; Guler Rajputs also became habitual of big umbrella, since Bhup Singh which is depicted in later royal paintings of Guler (12).

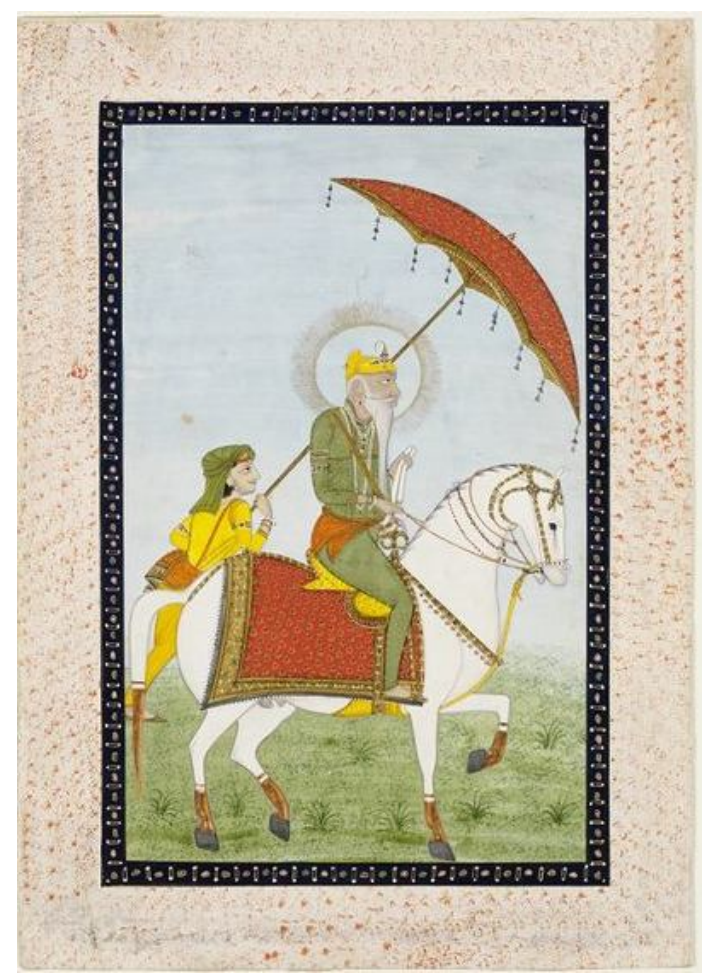

Figure 11. Maharaja Ranjit Singh. Circa 1838-184o (made) Museum no. IS.111-1953, Victoria and Albert Museum

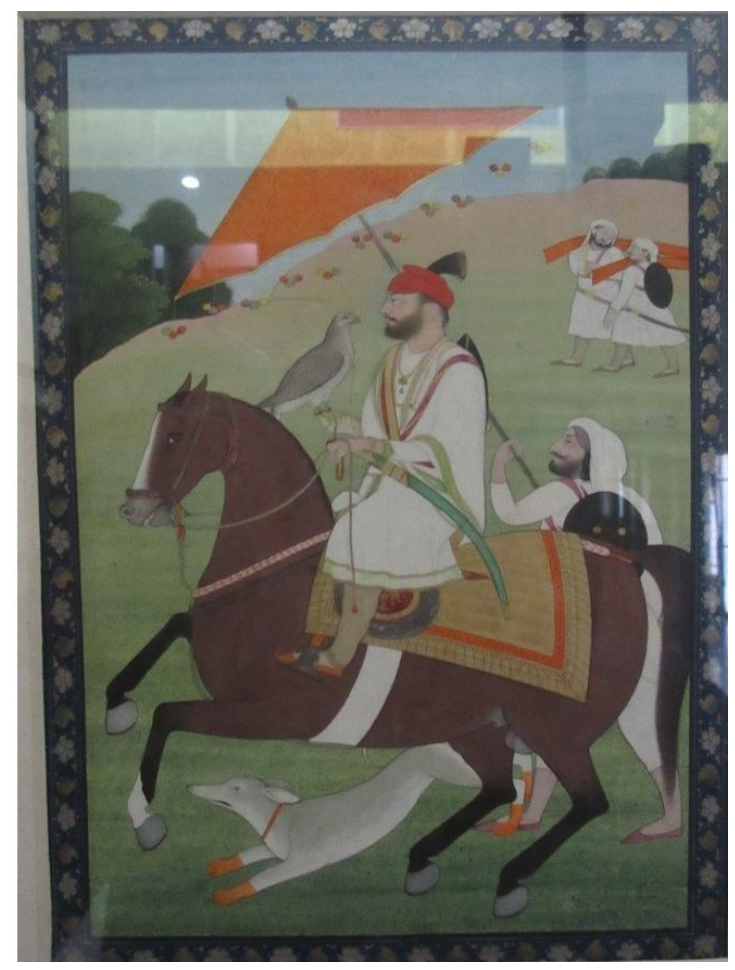


Figure 12. Raja Bhup Singh on horseback, circa 19th century A.D. Acc. no. 219, Government Museum and Art, Gallery, Chandigarh

\subsection{Weaving cloth}

Moorchala ${ }^{9}$ and chauri $^{10}$ were used for weaving the royals by attendants are not new in Indian painting but weaving by a white cloth is not much popular before Sikhs as this element is used popularly in the Sikh paintings (figure 13). The element of weaving with a cloth appeared earlier in the illustrations of Baburnama at Walters Art Museum and Laur-Chanda illustrations of Lahore museum, Lahore and Government Museum and art gallery, Chandigarh of mediaeval period. The element is also used in Rasikapriya illustrations of Mewar c. 1660. Later it became popular in Guler court scenes (figure 14).

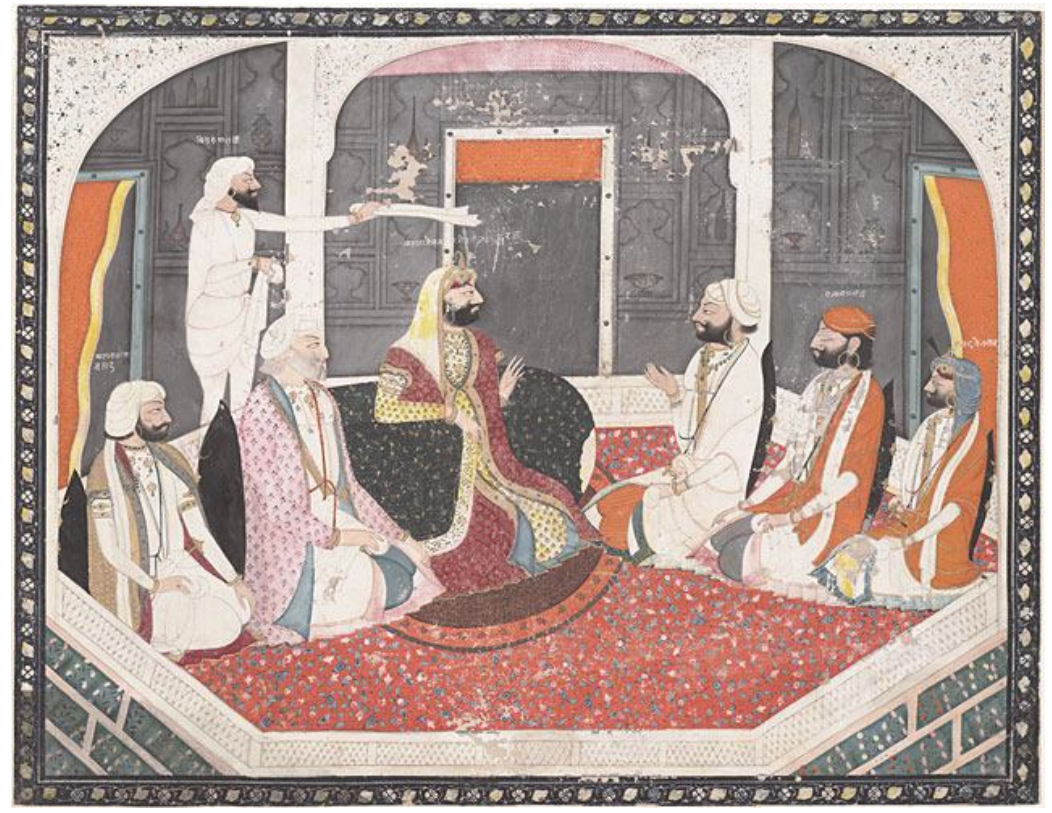

Figure 13. Maharaja Sher Singh and courtiers. Date: 1841 - 1843, Identifier: 1998.42.208, UC Berkeley, Berkeley Art Museum/ Pacific Film Archive

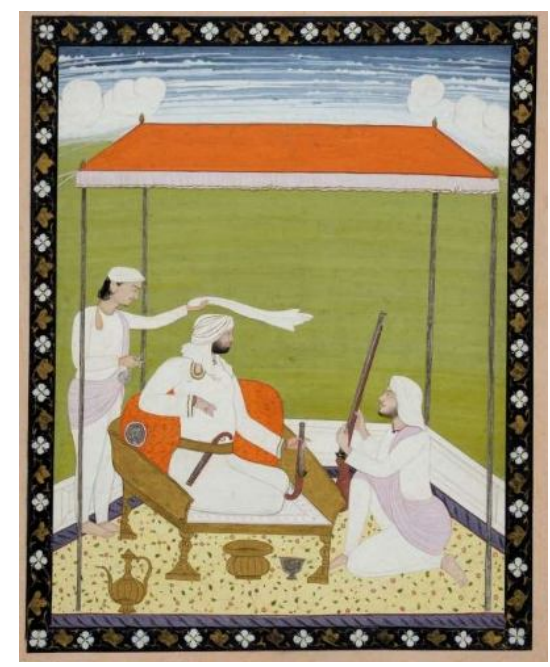


9 Chitrolekha International Magazine on Art and Design, Vol. 6, No. 3, 2016

Figure 14. Mian Jai Singh, inspecting a match lock. Guler, circa 186o, Acc. no. 224, Government Museum and Art Gallery, Chandigarh

\subsection{Cross-legged posture}

Maharaja preferred to sit 'Cross-legged in a golden chair' (Osborne 1840, 73) and 'sitting crosslegged in a large silver chair, very much resembling in shape what is called a hip bath' (Osborne 1840, 98-99) or reclining against a cushion on the Kashmiri carpet instead of a royal throne while Rajput rulers were often shown sitting on the square carpet in kneeling posture or laying on the low wooden beds reclining against oval cushion. The sitting posture of cross-legged became much popular among the Sikh courtiers and various Sikh portraits are in cross-legged posture. It also became popular among Guler Rajputs (figure 15) of nineteenth century along with kneeling posture.

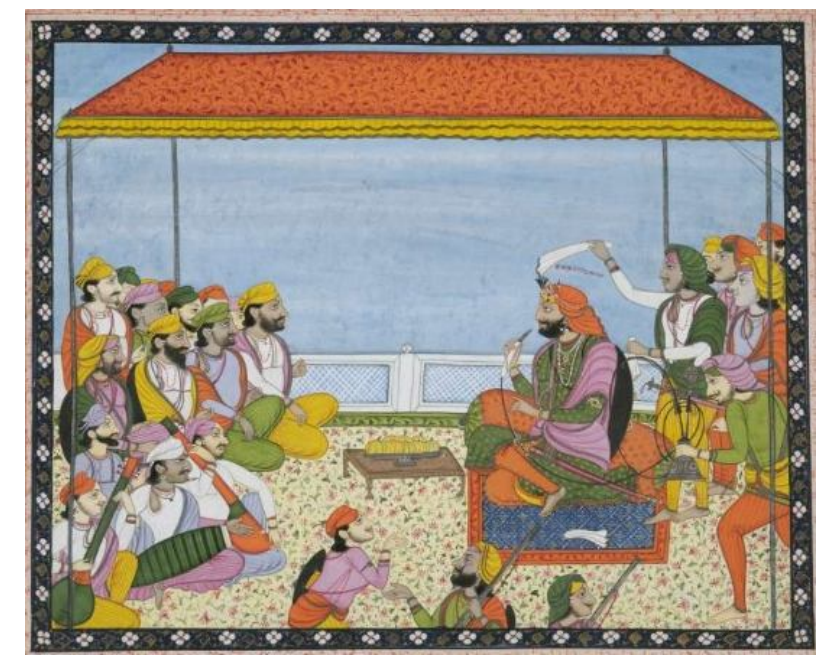

Figure 15. Mian Jai Singh listening to music played by male musicians. Guler, circa 1865 A.D. Acc. no. 212, Government Museum and Art Gallery, Chandigarh

\subsection{Golden-Silver chairs of English style with wooden stools}

Along with golden and silver arms after some alterations in popular in the Sikh court popular at Guler replacing stools were also popular at

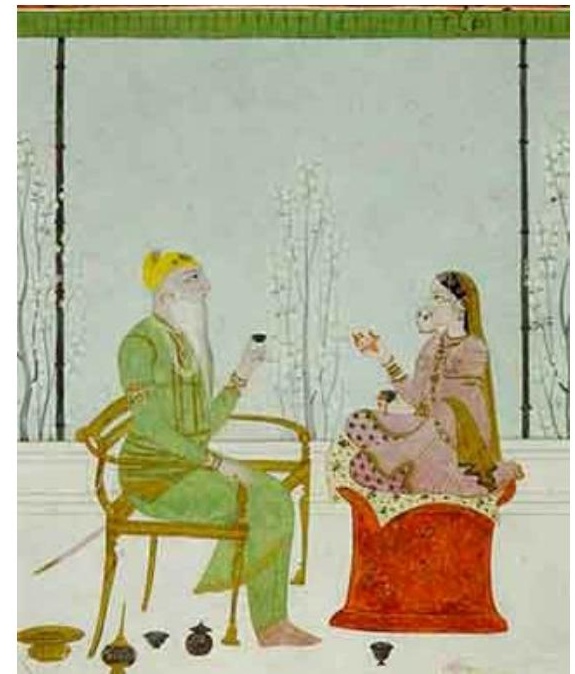

chairs; gilt chairs with looped English style chairs became (figure 16), and later became low wooden beds. Wooden Guler after Sikh influence. 
Figure 16. Maharaja Ranjit Singh (1786-1839) carousing with a Kangra lady. Circa 1830-1835, Indian Museum,

\subsection{Sikh attendant}

Calcutta.

The influence of Sikh lifestyle was not only expressed in courtly figures, but it also influenced common people working at Guler court (figure 15). Hindu attendants at Guler court appeared Sikh in late paintings because of Sikh dresses.

\subsection{Round Rugs}

Another object which influenced the Rajputs of Guler was round Kashmiri rug, which replaced the square shaped rugs and carpets.

\subsection{Shield}

In Mughal-Rajput common manners, a shield is worn at the waist with the help of a waist belt over right or left shoulder while standing. It is placed in the lap of a sitter during sitting posture. But in Rajputana, shields can also be seen at the back but in Mughal paintings of later times, shields began to appear seldom on back. So shields strapped on the back was not new, but this was never popular fashion with Guler rulers before Sikh influence. The fashion of wearing big black shield made of buffalo-hide strapped on the back was compulsory during Sikh Maharaja (figure 17) and nobles. ${ }^{12}$ This fashion influenced much on Guler rulers and expressed in Guler paintings of later times (figure 15).

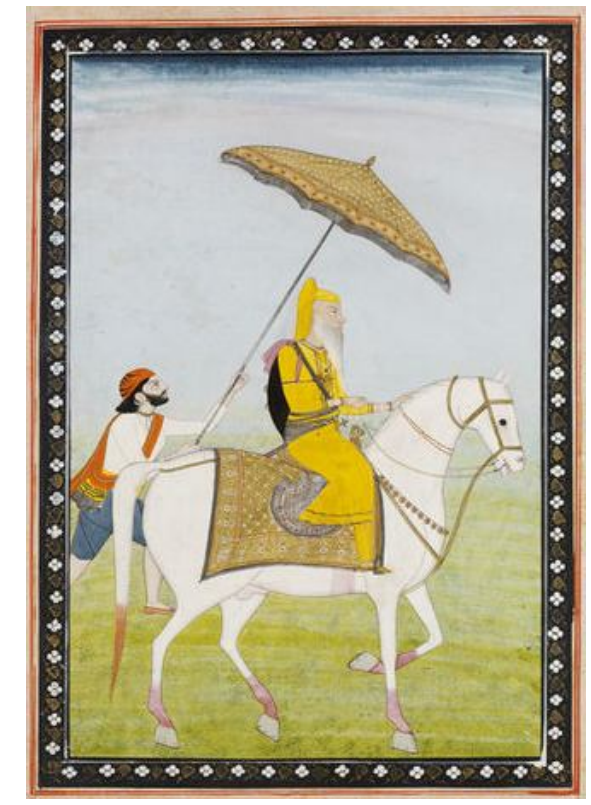

Figure 17. Maharaja Ranjit Singh, circa 1835-1840 (made) Museum no. IS.480-1950, Victoria and Albert Museum 
9 Chitrolekha International Magazine on Art and Design, Vol. 6, No. 3, 2016

\subsection{Uniform of troop}

Maharaja Ranjit Singh promoted the infantry battalion in India with the help of European officers. The uniforms of his troop were also designed after the influence of disciplined troops of East India Company. The influence of the uniforms of troops can be seen at Guler after the first decade of nineteenth century (figure 19). Before this, there were no uniforms for troops of Guler while Maharaja Sansat Chand of Kangra also designed the uniforms of their troop by Colonel O' Brian.

Maharaja's troop was always dressed in bright colored uniforms. Fitted uniform of Sikh troops contained velvet made jackets, blue-white trousers, turbans, black heron's plume, shirt of mail and embroidered cross-belts with finely polished amours with gold decorations (figure 18). A bag was also remained attached with cross-belts. The Sikh soldiers wore high jack boots and slippers decorated with golden embroideries. Long beards and mustaches gave them a distinct identity.

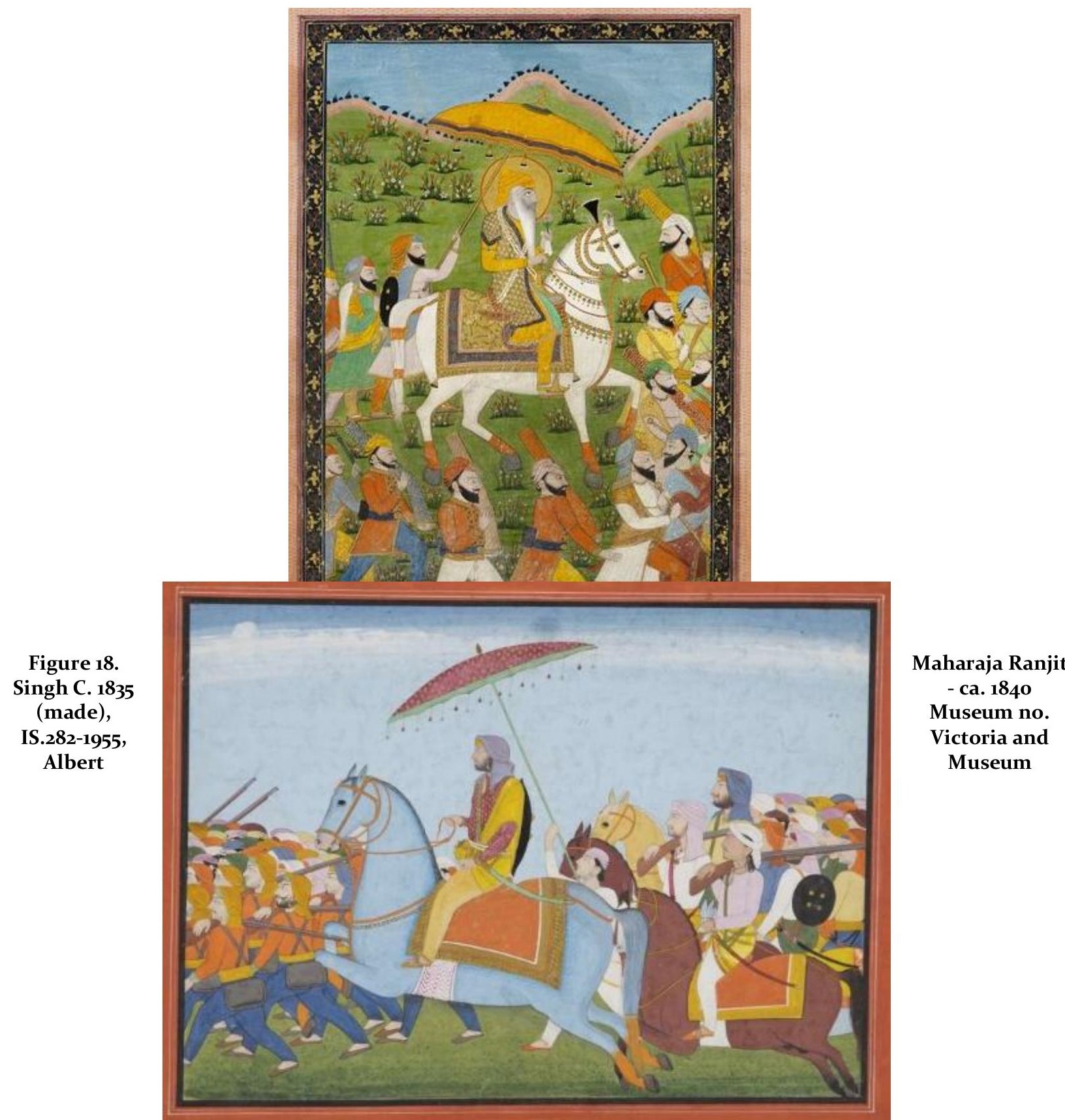


Figure 19. Mian Jai Singh of Guler riding with escort. Guler, circa 1845 A.D. Acc. no. 207, Government Museum and Art Gallery, Chandigarh.

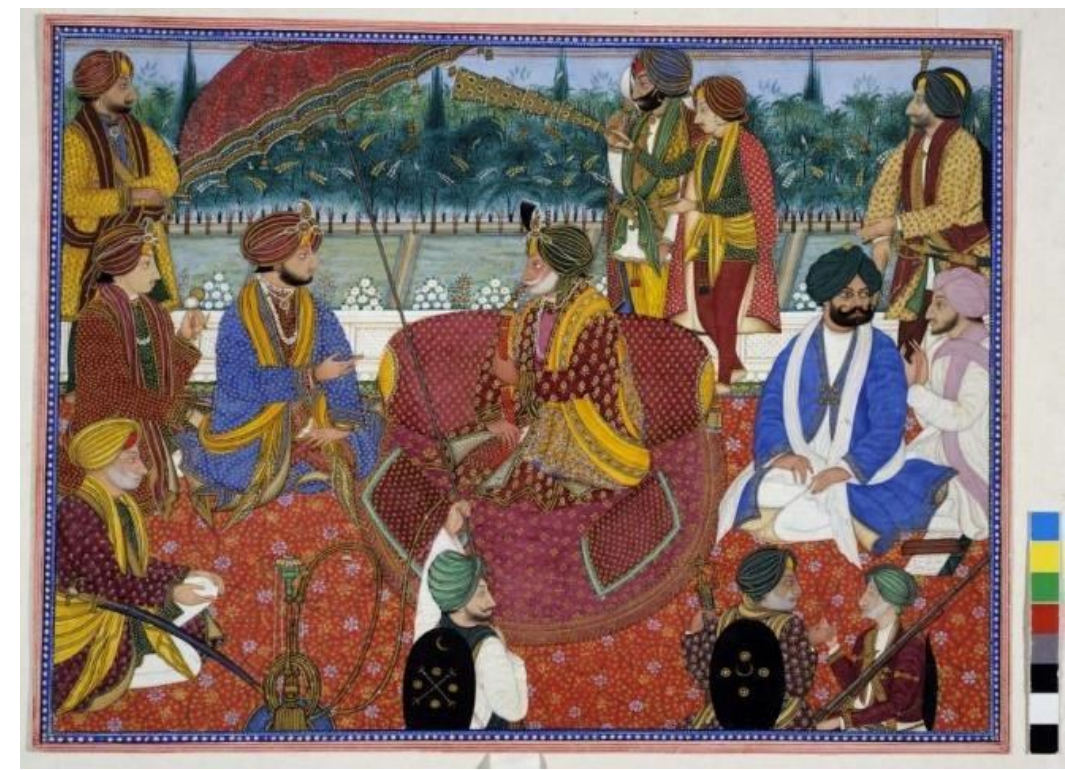

Figure 2o. Raja Jai Singh of Guler with Prince Raghunath Singh. Guler, 1882 A.D. Government Museum and Art Gallery, Chandigarh

\section{Conclusion:}

The scholars presume that families of painters migrated towards Punjab Hills from Punjab Plains or Delhi. It is obvious that painters of Punjab Hills were not unaware of Sikhism, which was a great social reformation for the low caste society while painters were also belonged to tarkhan caste, which is also assumed as low caste. Guler painters grasp the lifestyle of the common Sikhs of Punjab Plains from the beginning. Before the annexation of the Hills by Maharaja Ranjit Singh, during the first decade of nineteenth century, impression of Punjabi culture was little bit, and was 
not precise in Guler paintings. After the Sikh annexation of Guler since 18o9 A.D., Sikh influences are precise on the courtly life and paintings of Guler. When two different cultures involved, a type of alteration took place in two fashions and influenced each other. The whole atmosphere of the paintings is Rajput in originality but the air of Sikh influence makes it Sikh as the outer appearances of rulers and nobles had changed or manipulated and even after various adaptations by Rajputs, the Sikh influences are precise. The external Sikh influences could not change Rajput society entirely, but after various adaptations and continuous changes through person to person, Rajputs made external influences their own and amalgamate in their lives losing their own external Rajput identity. Guler rulers and courtiers gave preferences to the Sikh look not only in the regular life but also on the ceremonial occasions. To follow the court fashion by the folks is not new. So common natives of Guler were also remained under Sikh influences after Sikh annexation of Guler. Last phase of Guler paintings was full of Sikh impression entirely (figure 20). Although, Sikh regime ended with the annexation of Punjab by British rule but in Punjab Hills due to royal patronage, art of miniature painting continued in practice till the last quarter of nineteenth century but it remained under Sikh influences and image of Maharaja Ranjit Singh evoke the grandeur of Sikh Lahore court as well as the grand appearance of Sikh Maharaja can never elapsed till today in the hearts and minds of scholars.

\section{Notes}

${ }^{1}$ Literal meaning of 'rakhi' is protection.

${ }^{2}$ Singh, Khushwant. (2004). A history of the Sikhs, Vol. I: 1469-1838. Oxford University Press. 34

3 'Dumaala' is originated from the Persian word 'Dumbaalah' which means a tail. A small turban under a big turban usually worn by the Sikhs for the protection of head in the battlefield which shaped like a cone or tail on the end. Even today 'Dumaala' turbans are popular among Akali Nihangs.

${ }^{4}$ Gatra is a belt commonly made of cloth to wear a small sword.

${ }^{5}$ Goswamy, B. N. (1968). Pahari painting: the family as the basis of style. Bombay: Marg, Vol. XXI. 18-19

${ }^{6}$ Gupta, Hari Ram. (1984). History of the Sikhs, Vol. I, The Sikh Gurus 1469-1708. Munshiram Manoharlal Publishers Pvt. Ltd., see p. 37

${ }^{7}$ Singh, Khazan. (1914). History and philosophy of the Sikh religion, Part- I. Lahore: Newal Kishore press Ltd. 215

${ }^{8}$ Randhawa, M. S. (1961). Paintings from Arki, Roopa-lekha Vol. XXXII No. 1. New Delhi: AIFAACS. 25

${ }^{9}$ Flywhisk made of peacock feathers.

${ }^{10}$ Flywhisk made of yak tail.

${ }^{11}$ Bedekar, B. H. (2006). Chandigarh Museum Laur-Chanda, a study in styles. Chandigarh: Government Museum and Art Gallery. Plates- 5, 21

${ }^{12}$ Waheeduddin, Fakir Syed. (1965). The real Ranjit Singh. Pakistan: Lion art press, (Karachi) Ltd. See p. 126

\section{References}

Archer, W. G. (1973). Indian paintings from the Punjab Hills, (in two volumes), Oxford University Press. 
Bedekar, B. H. (2006). Chandigarh Museum Laur-Chanda, a study in styles. Chandigarh: Government Museum and Art Gallery.

Goswamy, B. N. (1968). Pahari painting: the family as the basis of style. Bombay: Marg, Vol. XXI.

Gupta, Hari Ram. (1984). History of the Sikhs, Vol. I, The Sikh Gurus 1469-1708. Munshiram Manoharlal Publishers Pvt. Ltd.

Hutchison and Vogel. (1933). History of the Punjab Hill States (in two volumes). Lahore

Latif Syad Muhammad. (1989). History of the Punjab. Reprinted, ISBN 81-7096-245-5. New Delhi: Kalyani Publishers.

Osborne, W. G. (1840). The court and camp of Runjeet Sing. London: Henry Colburn, Publisher.

Randhawa, M. S. (1961). Paintings from Arki. Roopa-lekha. Vol. XXXII No. 1. New Delhi: AIFAACS.

Randhawa M. S. and Randhawa D. S. (1982). Guler Painting. Publication division, Ministry and Information and Broadcasting, Government of India.

Singh, Khazan. (1914). History and philosophy of the Sikh religion. Part- I. Lahore: Newal Kishore press Ltd. Singh, Khushwant. (2004). A history of the Sikhs. Vol. I: 1469-1838. Oxford University Press.

Waheeduddin, Fakir Syed. (1965). The real Ranjit Singh. Pakistan: Lion art press, (Karachi) Ltd.

Gurdeep Kaur, Research scholar of Fine Arts, Lovely Professional University, Phagwara, India. Email:gurdeepkaur121@yahoo.in.

Dr. Rohita Sharma, Assistant professor, Lovely Professional University, Phagwara, India. Email. rohita.19359@lpu.co.in. 